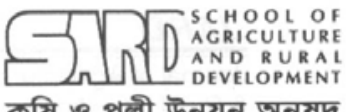

কৃষि ও পল্লী উন্ময়ন অনুষদ
Available online at

http:/ / www.banglajol.info/index.php/jard
J ARD

Journal of Agriculture \& Rural Development

\title{
Determination of Inhibitory Action of Allamanda Leaf Extracts Against Some Important Plant Pathogens
}

\author{
S. MAsuduzZaman ${ }^{1}$, M. B. MeAH $^{1}$ \& M. M. RASHID ${ }^{2 *}$ \\ ${ }^{1}$ Department of Plant Pathology, Bangladesh Agricultural University, Mymensingh, Bangladesh \\ ${ }^{2}$ Bangladesh Rice Research Institute, Regional Station, Sonagazi, Feni, Bangladesh
}

\begin{abstract}
Allamanda leaf extract and separated compounds were studied to determine their inhibitory efficiency against Phomopsis vexans, Fusarium sp, Rhizoctina solani, Sclerotiurn rolfsii and Phytophthora capsici. Four concentrations of the extract namely 1:1, 1:2, 1:3 and 1:4 were used. Extract at 1:3 concentration completely inhibited mycelial growth of $P$. vexans while other three concentrations were also near completely inhibitory. No concentration showed good performance to inhibit mycelial growth of Fusarium sp. But all concentrations completely inhibited the growth of mycelia of R. solani. Higher concentration $(1: 1,1: 2)$ completely inhibited S. rolfsii whereas lower concentration $(1: 3,1: 4)$ arrested its growth to some extent. Incase of $P$. capsici, though 1:3 concentration completely inhibited mycelial growth but other three were also promising. For separated compounds, compound 1 and 3 completely inhibited the growth of $P$. vexans, the other one was not so much promising. In case of Fusarium sp and R. solani, compound 3 showed partial inhibition, but the same compound completely inhibited the growth of S. rolfsii and P. capsici. Water extract showed better performance compared to separated compounds which indicated that some of the essential compounds for the inhibitory action might have been removed during preparation of extracts in other solvents.
\end{abstract}

Key words: Allamanda, leaf extracts, compounds, plant pathogens, efficiency.

\section{INTRODUCTION}

Eggplant is the second most important vegetable crop, next to potato in respect of total acreage (62.753 ha) and production (3,70,000 mt annually) in Bangladesh (BBS, 2003). Such a potential crop is known to suffer from many diseases and among them seedling diseases are very important. Seedling diseases are damping off, seedling blight. etc caused by Phomopsis vexans, Fusarium sp, Rhizoctina solani, Sclerotiurn rolfsii and Phytophthora capsici. These diseases cause crop loss up to $30-50 \%$ affecting 8 million farm families involved in eggplant cultivation (Anon., 2004). An annual loss of Tk. 808 million has been estimated for some $20 \%$ crop loss in eggplant for the disease (Meah, 2002). To control these diseases for commercial production system of this vegetable and for their quality and high productivity per unit area, the synthetic pesticides are being used indiscriminately at large scale. Consumption of pesticides in Bangladesh were $10136.83 \mathrm{mt}$. (BBS, 2003), of which fungicides were $3445.2 \mathrm{mt}$. This causes serious environment pollution and human health.

* Corresponding author: Scientific Officer, BRRI, Regional Station, Sonagazi, Feni, Cell:01712887507, E-mail: mirza_26658@yahoo.com

(C) 2008 School of Agriculture and Rural Development, Bangladesh Open University, All rights reserved. 


\section{S. Masuduzzaman et al.}

The efforts are being made to explore suitable alternatives as substitutes for synthetic pesticides. Research and development agencies in various parts of the world have intensified their research program in search of such botanical and biological pesticides for management of vegetable diseases in order to reduce the use of chemicals. Some progress has been made for example the leaf extracts of Ocimum sanctum $L$ were found to be potent fungicides against rice blast caused by Pyricularia grisea [Magnaporthe grisea] (Tewari, 1995). The botanical fungicide Nimbicidin (3\%) was found effective in reducing the fruit rot disease of chili by $64 \%$ (Hegde and Anahosur, 2001) and the botanical fungicide Tithonia diversifolia showed a good control against fruit rot, anthracnose and cercospora leaf spots of hot pepper, its efficacy was equal to the application of mancozeb $0.2 \%$ (Duriat, 1999).

Many plant and plant products have been reported to be antimicrobials against plant pathogenic fungi (Bowers and Locke, 2000; Lawson and Dennedy, 1998; Grayer and Harbome, 1994; Shetty et al., 1984). Plant extracts might be a substantial alternative of chemical pesticides in controlling plant diseases. Allamanda leaf extract is one of them which shows miracle result in controlling plant diseases (Meah et al., 2002). So far it has been shown effective against Phomopsis vexans and Sclerotium rolfsii (Khan, 1999; Rumana, 2004), not tested against other fungi which are also involved in nursery diseases. Allamanda (Allamanda cathertica) leaves are the source of many compounds with medicinal properties thus supporting many of the medicinal uses of allamanda .

The information on the effect of botanical extracts on the seedling diseases is not available. Therefore, the efficacy of both botanical extract and separated compounds of allamanda is necessary. In the past couple of years, trials on the use of garlic bulb extract against several fungi were made. The results of the trials against Phomopsis vexans, Sclerotium rolfsii and other fungi in the laboratory and in the nethouse were highly promising (Islam, 2005). The effect of allamanda extract was also promising against fungi (Khan, 1999; Meah et al., 2002; Rumana, 2004). In continuation of the study, it is very necessary to know the effect of biological extract and separated compounds made from allamanda on the seedling pathogens like Phomopsis vexans, Fusarium sp, Rhizoctina solani, Sclerotiurn rolfsii and Phytophthora capsici. Therefore the present research was undertaken to delermine the specificity of the inhibitory action of compound (s) in allamanda extract against five important plant pathogens.

\section{MATERIALS AND METHODS}

The experiment was conducted at the IPM Laboratory, Department of Plant Pathology and Chemistry Laboratory, Department of Chemistry, Bangladesh Agricultural University (BAU), Mymensingh during December 2005 to November 2006.

\section{Allamanda water extract preparation}

Allamanda leaves were collected from BAU campus, mixed with equal amount of water, grinded in mortar and finally sieved through muslin cloth to obtain 1:1 solution. Dilution to 1:2, 1:3 and 1:4 was done simply by adding water.

\section{Allamanda chemical extract preparation}

Allamanda leaves collected from BAU campus were dried and powdered as far as possible by mortar and pestle. One hundred grams of powdered leaves were taken and $200 \mathrm{ml}$ methylene chloride was added to it. The mixture was kept over night at room temperature $\left(25 \pm 2^{0} \mathrm{C}\right)$. The mixture was then shaken for two hours in a flask shaker, afterwards filtered through cheese cloth followed by filtration through filter paper Whatman No. 1.

\section{Preparation of refluxing extracts of allamanda by using Soxlet's apparatus}

Some important compounds in allamanda seemed to be unstable so they decompose readily. For this reason, at first allamanda leaf extract was made under normal temperature. They were extracted by refluxing in low boiling solvents like methylene chloride. For preparation of refluxing extract $50 \mathrm{~g}$ of dried and powdered allamanda leaves were taken in a thimble, added $200 \mathrm{ml}$ methylene chloride in the thimble. This was done by Soxlet's apparatus in a water bath keeping the 
temperature at $40 \pm 2^{\circ} \mathrm{C}$. These extracts were partially concentrated and used for testing against Phomopsis vexans, Fusarium sp, Rhizoctina solani, Sclerotiurn rolfsii and Phytophthora capsici. TLC of these reflux extracts was done and $R_{f}$ values of the colored and colorless spots were determined.

\section{Thin layer chromatography}

Thin layer chromatographic (TLC) technique was employed for the identification of a number of compounds present in the extracts. TLC of the extracts were made by using different solvents and mixed solvents. A number of spots were seen for different compounds. Their $R_{f}$ values were determined.

\section{Column chromatography}

A chromatographic column is a long glass tube having $100 \mathrm{~cm}$ length and $12 \mathrm{~cm}$ breadth and packed with particles of stationary phase Silica gel $(0.063-0.200 \mathrm{~mm})$. The space between the particles was completely filled with a non polar solvent hexane which moves under the influence of gravity and pass out at the bottom through the porous support. The column was irrigated with the mobile phase until the desired components of the mixture eluted or separated on the column. The flow rate depends on the dimensions of the column. About $250 \mathrm{ml}$ moving solvent was added above the stationary phase and $200 \mathrm{ml}$ elute was collected in equal volumes by means of a fraction collector. The number of the fraction may range up above thirty. The elute was placed in a water bath to remove the solvent and a small residue was collected. TLC of this residue was made by using different solvents and mixed solvents.

The sequences of solvents used in column were 1) Hexane, 2) Benzene, 3) Ethyl acetate and 4) Methylene chloride.

The sequence of mixed solvents used in column were a) Hexane:Benzene $=3: 1, b$ ) Hexane:Benzene = 1:1, c) Hexane:Benzene = 1:3, d) Benzene:Ethyl acetate = 3:1, e) Benzene:Ethyl acetate = 1:1, f) Benzene:Ethyl acetate $=1: 3, \mathrm{~g}$ ) Ethyl acetate:Methylene chloride = $3: 1$, h) Ethyl acetate:Methylene chloride $=1: 1$, i) Ethyl acetate:Methylene chloride $=1: 3$.

\section{Calculation of $\mathbf{R}_{\boldsymbol{f}}$ values of spots appeared in TLC}

When solvent front passed more than half of the TLC plate, it was marked and the plates were taken out and allowed to dry. The plates were then placed in iodine chamber and $R_{f}$ (Ratio of flow) values were calculated as follows:

$$
\mathrm{R}_{\mathrm{f}}=\frac{\text { Distance traveled by the component molecules from the starting point }}{\text { Distance traveled by the solvent front from the starting point }}
$$

\section{Collection and maintenance of culture of the pathogens}

Isolate-22 of $P$. vexans, $S$. rolfsii and Fusarium sp. were collected from IPM Lab, $P$. capsici was collected from Department of Plant Pathology, BAU and R. solani from BINA, Mymensingh. The fungi were multiplied in PDA (Potato Dextrose Agar) and the cultures were stocked in PDA slant for future use.

\section{Bio-assay of extracts}

Allamanda solution at four concentrations (1:1, 1:2, 1:3 and 1:4) were tested separately against $P$. vexans, Fusarium sp, $R$. solani, $S$. rolfsii and $P$. capsici in vitro following growth inhibition technique (Meah et al., 2002). Linear growth of the fungus was taken after 24, 48, 72 and 96 hours.

\section{Bio-assay of separated compounds}

Separated compounds of allamanda collected through column chromatography were dissolved individually in a polar solvent methylene chloride. Methylene chloride is a volatile solvent and it has no considerable effect on the growth of the test fungi as checked in vitro following growth inhibition techniques. Bioassay of the compounds was accomplished following the procedure as described for the bioassay of extracts (Meah et al., 2002). 


\section{S. Masuduzzaman et al.}

Data collected on different parameters were analyzed following Completely Randomized Design (CRD) using statistical computer package program MSTAT. Means were compared with Duncan's Multiple Range Test (DMRT) (Gomez and Gomez, 1984).

\section{RESULTS}

\section{Effect of allamanda leaf water extract against five different fungi}

Allamanda leaf water extract inhibited completely the mycelial growth of $P$. vexans at 1:3 concentration while $66.67 \%$ growth was inhibited at 1:1 concentration. In case of Fusarium, the extract at $1: 1$ concentration $41.45 \%$ growth was arrested while other concentrations were ineffective. Allamanda leaf extracts completely inhibited growth of $R$. solani at all concentrations. The growth of $S$. rolfsii was completely inhibited at conc. 1:1 and 1:2 while other two concentrations were partially effective. Allamanda leaf water extract at 1:3 concentration inhibited the mycelial growth of $P$. capsici completely while conc. 1:1 and 1:2 were near completely effective and concentration 1:4 was partially effective (Table 1).

Table 1. Effect of allamanda leaf extract against five plant pathogenic fungi

\begin{tabular}{cccccc}
\hline $\begin{array}{c}\text { Concentration of } \\
\text { Leaf Extract }\end{array}$ & \multicolumn{4}{c}{ \% Growth inhibition of mycelia after 96 hours of inoculation } \\
\cline { 2 - 6 } & $\begin{array}{c}\text { Phomopsis } \\
\text { vexans }\end{array}$ & Fusarium sp. & $\begin{array}{c}\text { Rhizoctonia } \\
\text { solani }\end{array}$ & $\begin{array}{c}\text { Sclerotium } \\
\text { rolfsii }\end{array}$ & $\begin{array}{c}\text { Phytophthora } \\
\text { capsici }\end{array}$ \\
\hline $1: 1$ & 66.67 & 41.45 & 100.00 & 100.00 & 95.37 \\
$1: 2$ & 66.67 & 9.32 & 100.00 & 100.00 & 94.22 \\
$1: 3$ & 100.00 & 2.07 & 100.00 & 72.78 & 100.00 \\
$1: 4$ & 16.66 & 8.29 & 100.00 & 60.13 & 87.86 \\
\hline
\end{tabular}

\section{TLC of compounds separated by chromatographic column from allamanda leaf extract using different solvents as eluent}

TLC of three compounds separated from allamanda leaf extracts were eluted by different solvents which were developed by iodine chamber. Through using many solvents, only three solvents near able to release three active compounds from allamanda leaf extracts (Table 2).

Table 2. Compounds from allamanda leaf extracts using different eluent solvents

\begin{tabular}{ccc}
\hline Compounds & Eluent solvents & Ratio \\
\hline 1 & Hexane:Benzene & $1: 1$ \\
2 & Hexane & - \\
3 & Benzene:Ethyl acetate & $1: 1$ \\
\hline
\end{tabular}

\section{Effect of allamanda compounds against five different fungi}

Compounds 1 and 3 completely inhibited the growth of Phomopsis vexans while compound 2 initially displayed some inhibitory action but finally it was found ineffective. Among the three compounds, compound 3 was found partially inhibitory to Fusarium sp. while other two compounds were found ineffective. In case of Rhizoctonia solani, compounds 1 and 2 were totally ineffective while compound 3 reduced mycelial growth by $74 \%$. Compound 3 inhibited completely the growth of Sclerotium rolfsii while compounds 1 and 2 arrested the growth of S. rolfsii by $49 \%$ and $43 \%$, respectively. All the three compounds were effective against Phytophthora capsici (Table 3).

Table 3. Effect of allamanda leaf compounds against five plant pathogenic fungi

\begin{tabular}{cccccc}
\hline \multirow{2}{*}{ Compound } & \multicolumn{4}{c}{ \% Growth reduction of mycelia after 96 hours of inoculation } \\
\cline { 2 - 5 } & $\begin{array}{c}\text { Phomopsis } \\
\text { vexans }\end{array}$ & Fusarium sp. & $\begin{array}{c}\text { Rhizoctonia } \\
\text { solani }\end{array}$ & $\begin{array}{c}\text { Sclerotium } \\
\text { rolfsii }\end{array}$ & $\begin{array}{c}\text { Phytophthora } \\
\text { capsici }\end{array}$ \\
\hline 1 & 100.00 & 11.40 & 6.48 & 49.05 & 97.10 \\
2 & 13.00 & 5.71 & 10.44 & 43.29 & 92.74 \\
3 & 100.00 & 50.76 & 74.20 & 100.00 & 100.00 \\
\hline
\end{tabular}




\section{Comparative effect of allamanda leaf extract and the compounds separated thereof against some plant pathogenic fungi}

Allamanda leaf extract was found effective in inhibiting all but Fusarium sp. at one or more concentration. The compounds separated from leaf extract displayed variable inhibitory action. Out of three compounds, not a single one was found effective against all the test fungi. Compound 1 was found effective against Phomopsis vexans, compound 2 to none while compound 3 was found effective against $P$. vexans, Sclerotium rolfsii and Phytophthora infestans. Though allamanda leaf extract at all concentration completely inhibited growth of Rhizoctonia solani, none of the three compounds displayed such action.

\section{DISCUSSION}

Allamanda extract in water has been found to be very much effective against nursery diseases. This was established by Khan (1999) and others. Hawlader (2003) reported that seed treatment with allamanda leaf extracts effectively increased germination of eggplant seeds and tremendously decreased nursery diseases. This has conformity with the findings of Panda et al. (1996) who reported leaf extracts of Allamanda cathertica as an excellent potential fungicide for control of nursery diseases.

Khan (1999) found that the incidence and severity of the disease varied when aqueous leaf of Neem, Allamanda and Bael were applied at flowering and peak fruiting stages in 3 different doses (S, S/10 and S/100). Allamanda (S) was most effective to reduce leaf and fruit infection rates and lesion size as well followed by Bael (S). However, Khan (1999) did try in vitro lab assay the effectiveness of different plant extracts against nursery diseases. Panda et al. (1996) tested efficacy of leaf extracts of Debdaru, Thuza, Allamanda, Bael and Kathgolap and obtained excellent potential from leaf extracts of Allamanda against nursery diseases.

These findings prompted us to find out appropriate ratio and chemical investigation of allamanda extracts. Our primary views were to make an water extract and separate compound avoiding unexpected constituents in these extracts and compounds. Secondly, we became interested to find out the appropriate ratio and effective compound or compounds in allamanda which were responsible for such antifungal activity.

Four allamanda concentrations were made in by water. Refluxing methylene chloride was used for column chromatographic separation of active components in allamanda leaves. In column chromatography, elution was done by non polar to highly polar solvents and mixed solvents which enabled to separate three single compounds from allamanda leaves. These were some of the different compounds present in allamanda leaf extract.

\section{CONCLUSION}

Allamanda water extract and separated compounds displayed differential inhibitory action against five plant pathogenic fungi. Water extracts of allamanda leaves exhibited higher inhibitory action against five pathogens than separated compounds. It indicates that some of the components essential for the inhibitory action might have been removed during the preparation of extracts in other solvents, even though allamanda water extracts and separated compounds proved having antifungal properties and a potential source of biological control of plant pathogens. The future research should focus separate the active compound in adequate amount through column chromatography or any other easiest direct method and determine the structure of active compound for commercial formulation of botanical fungicide.

\section{LITERATURE CITED}

Anonymous. 2004. Development of an Integrated Approach for Management of Phomopsis Blight and Fruit Rot of Eggplant in Bangladesh: Annual Research Report (2003-2004), USDABangladesh Collaborative Research Project (No. 99/24/USDA), Department of Plant Pathology, Bangladesh Agricultural University, Mymensingh. pp. 4-27. 


\section{S. Masuduzzaman et al.}

BBS. 2003. "Year Book of Agricultural Statistics of Bangladesh". Statistics Division, Bangladesh Bureau of Statistics, Ministry of Planning, Government of the Peoples' Republic of Bangladesh. $55 \mathrm{pp}$.

Bowers, J. H. and Locke, J. C. 2000. Effect of botanical extracts on the population density of Fusarium oxysporum in soil and control of Fusarium wilt in the greenhouse. Plant Dis 84, 300-305.

Duriat, A. S. 1999. Non-chemical control of pests and diseases of hot pepper. Indonesian Agril. Res Dev J 21(2), 21-26.

Gomez, K. A. and Gomez, A. A. 1984. "Statistical Procedures for Agricultural Research" (Second Edn.). John Wiley and Sons, New York, 680 pp.

Grayer, R. J. and Harbome, J. B. 1994. A survey of antifungal compounds from higher plants. Phytochemistry 37, 19-42.

Hawlader, A. N. 2003. Effect of seed selection and seed treatment on the development of Phomopsis blight and fruit rot of eggplant. Unpublished [MS Thesis], Department of Plant Pathology, Bangladesh Agricultural University, Mymensingh. pp 40-68.

Hegde, G. M. and Anahosur, K. H. 2001. Evaluation of fungitoxicants against fruit rot of chilli and their effect on biochemical constituents. Karnataka J Agril Sci 14(3), 836-838.

Islam, M. R. 2005. An Integrated approach for management of phomopsis blight and fruit rot of eggplant. Unpublished [PhD Thesis], Department of Plant Pathology, Bangladesh Agricultural University, Mymensingh. $167 \mathrm{pp}$.

Khan, N. U. 1999. Studies on epidemiology, seed-borne nature and management of Phomopsis fruit rot of brinjal. Unpublished [MS Thesis], Department of Plant Pathology, Bangladesh Agricultural University, Mymensingh, pp. 38-68.

Lawson, M. and Dennedy, R. 1998. Evaluation of garlic oil and other chemicals for control of downey mildew (Peronospora parasitica) in organic production of brassicas. Ann Appl Biol 132(suppl), 14-15.

Meah, M. B. 2002. Development of an integrated approach for management of Phomopsis blight/fruit rot of eggplant in Bangladesh. BAU Res Prog 12, 33.

Meah, M. B., Hossain, M. D. and Islam, M. R. 2002. Development of an Integrated Approach for Management of Phomopsis Blight and Fruit Rot of Eggplant in Bangladesh: Annual research report (2001-2002), Department of Plant Pathology, Bangladesh Agricultural University, Mymensingh, Bangladesh. $25 \mathrm{pp}$.

Panda, R. N., Tripathy, S. K., Kar, J. and Mahanty, A. K. 1996. Antifungal efficacy of homeopathic drugs and leaf extracts on brinjal. Environ Ecol 14(2), 292-294.

Rumana, I. 2004. Chromatographic separation of components in garlic bulb and allamanda leaf extracts inhibitory to Phomopsis vexans. Unpublished [MS Thesis], Department of Plant Pathology, Bangladesh Agricultural University, Mymensingh. 35 pp.

Shetty, S. A.; Prakash, H. S. and Shetty, H. H. 1984. Efficacy of certain plant extracts against seed-borne prevalence of Trichoconiella padwickki in paddy (Oryza sativa). Canadian J Bot 67(7), 1956-1958.

Tewari, S. N. 1995. Ocimum sanctum L., a botanical fungicide for rice blast control. Tropic Sci 35(3), 263-273. 